in response to the slower than normal tissue blood flow. The normal values for standard bicarbonate and base excess in varicose vein blood indicate the absence of any significant tissue metabolic acidosis and support the above interpretation of the results.

Treatment with Paroven significantly altered the $\mathrm{Po}_{2}$, oxygen saturation, and the oxygen content of varicose vein blood and the oxygen extraction in tissues of varicose vein legs towards normal values. The improved venous blood oxygenation and the reduced tissue oxygen extraction indicated better tissue perfusion with less blood oxygen having been taken from the increased capillary blood flow. The unchanged venous blood metabolic acid-base values probably implied some upwards adjustment in the level of tissue metabolism, since an unchanged tissue metabolism and an increased blood flow would have resulted in a fall in $\mathrm{PCO}_{2}$ and a rise in $\mathrm{pH}$ in venous blood, and this was not observed.

There was an interesting relationship between symptomatic improvement and objective measurements recorded after treatment with Paroven. The seven patients who reported symptomatic relief had an average increase in varicose vein blood $\mathrm{PO}_{2}$ of $8.1 \mathrm{~mm} \mathrm{Hg}$ and the two patients who experienced no symptomatic relief had an average increase in varicose vein blood $\mathrm{PO}_{2}$ of only $4.8 \mathrm{~mm} \mathrm{Hg}$. The proof of a direct correlation between blood gas changes and symptomatic improvement would require a double-blind trial of Paroven and was outside the scope of this study.

Tissue hypoxia, in the sense that oxygen supply was insufficient for the prevailing level of metabolism, did not seem to be present in legs affected by varicose veins. There was, however, good evidence to support the view that capillary blood flow or tissue perfusion was below the normal optimum level. A four-week course of Paroven seemed to have signifi- cantly improved tissue perfusion and oxygenation by its known vasoactive effect. This was accompanied by the previously recorded amelioration of the symptoms attributed to venous insufficiency. In the apparent absence of tissue hypoxia and acidosis these symptoms would therefore seem to have been due simply to extracellular fluid accumulation and venule and capillary distension.

Supplies of Paroven and details of previous investigations of the action and effect of $O$-( $\beta$-hydroxyethyl) rutosides were made available by Dr. A. David, Zyma (United Kingdom) Limited.

\section{References}

Allen, S. (1970). Practitioner, 205, 221.

Comroe, J. H., Dripps, R. D., Dumke, P. R., and Denning, M. (1945). Fournal of the American Medical Association, 128, 710.

DeTakats, G., Quint, H., Tillotson, B. I., and Crittenden, P. J. (1929) Archives of Surgery, 18, 671.

Fabre, J., and Rudhardt, M. (1962). Médecine et Hygiène, 20, 161.

Fitzgerald, D. E. (1967). Practitioner, 198, 406.

Foelsche, W. (1968). Fortschritte der Medizin, 86, 273.

Fontaine, R. (1957). Surgery, 41, 6.

Ghittoni, S., and Martini, P. (1967). Anthologica Medica Santoriana, 81, 1. Harrison, R. G. (1967). British fournal of Dermatology, 79, 9.

Ledingham, I. McA., McBride, T. I., Parratt, J. R., and Vance, J. P. (1970). Fournal of Physiology, 210, 87.

McDowall, D. G., Ledingham, I. McA., and Tindal, S. A. P. (1968). Fournal of Applied Physiology, 24,324.

McEwan, A. J., Stalker, C. G., and Ledingham, I. McA. (1970). British Medical fournal 3,612 .

Pfister, R., and Lindner, U. (1967). Therapiewoche, 17, 674

Pfister, R., and Lindner, U. (1967). Therapiewoche, 17, 674.

Pinlachs, P., and Vidal-Barraquer, F. (1953). Angiology, 4, 59. Médecine de Lyon, $\mathbf{5 1}, 1180,501$.

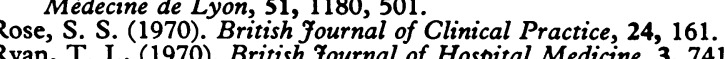

Ryan, T. J., (1970). British fournal of Hospital Medicine, 3, 741

Swart, E. (1970). Unpublished results.

Torres, G. E. (1963). Fournal of Applied Physiology, 18, 1008.

\title{
Contact Dermatitis from Penetration of Rubber Gloves by Acrylic Monomer
}

\author{
J. S. PEGUM, F. A. MEDHURST
}

British Medical fournal, 1971, 2, 141-143

\section{Summary}

An orthopaedic surgeon developed dermatitis from acrylic materials. The acrylic monomer was found to penetrate surgical rubber gloves readily. Cases of "rubber glove dermatitis" with negative patch tests may have a similar explanation. Laboratory tests suggest that monomer does not damage rubber sufficiently to allow bacteria to penetrate gloves, but it remains possible that this would happen under theatre conditions.

\section{Case History}

An orthopaedic surgeon developed a rash on the hands in January 1970. A number of years previously he had had a rash of the hands

\section{London Hospital, London E1 1BB}

J. S. PEGUM, M.D., F.R.C.P., Physician to Skin Department, London Hospital Medical College, London E1 1BB

F. A. MEDHURST, PH.D., Lecturer in Bacteriology attributed to the use of disposable rubber gloves. This had resolved when solution gloves were substituted. Examination showed redness and scaling of the palm, the palmar surface of the fingers, and the finger-webs of the left hand. The tops of the right index and little fingers were similarly affected. The rash was improved by steroid ointment but tended to relapse within an hour of the finish of operating sessions.

Patch tests to the gloves, the glove powder, and the other obvious things related to operating procedures were negative. When operating on the hip he used acrylic cement to secure a plastic acetabulum and a stainless steel prosthetic substitute for the head of the femur. He moulded the cement in the left palm and then rammed the mass into the acetabulum and into the cavity of the femur, using the tip of the right index finger and the tip of the right little finger. These were exactly the areas affected. Though it seemed unlikely that the cement would penetrate intact rubber gloves, patch tests were done and proved strongly positive. Tests in which the acrylic monomer was enclosed in the sealed finger of a rubber glove were also positive. An in-vitro test recorded below confirmed that monomer rapidly penetrated intact rubber gloves. The surgeon then took care not to handle the bone cement and the hands gradually improved. On one occasion, however, he forgot his hypersensitivity and used the cement. This was followed by a rapid relapse. The skin settled again and when last seen (November 1970) the hands were quite normal apart from slight scaling and redness of the tip of the left index finger. 


\section{Investigations}

VARIOUS TESTS

Patch testing and tests to find out if acrylic materials penetrate rubber gloves were performed. The self-curing acrylic cement (C.M.W. bone cement) consists of a liquid and a powder (Charnley, 1970). The two are mixed and form a dough which sets hard in 5 to 10 minutes. The liquid consists of methylmethacrylate monomer, which is stabilized by the addition of a small amount of ascorbic acid, and also contains $2 \%$ of dimethylparatoluidine, which is a catalyst. It will be seen from the Table of patch test results that this liquid in a concentration of $5 \%$ in acetone gave strongly positive patch test reactions, while tests with dimethylparatoluidine and ascorbic acid were negative.

\section{Patch Test Results}

\begin{tabular}{|c|c|c|}
\hline Substance & $\begin{array}{l}\text { Concentration } \\
\text { Vehicle }\end{array}$ & Result \\
\hline 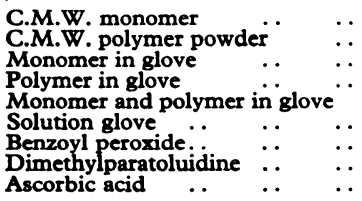 & $\begin{array}{l}5 \% \text { in acetone } \\
\text { as is } \\
\text { as is } \\
\text { as is } \\
\text { as is } \\
\text { as is } \\
10 \% \text { petroleum jelly } \\
2 \% \text { petroleum jelly } \\
2 \% \text { water }\end{array}$ & $\begin{array}{c}+ \\
\text { Negative } \\
+ \\
+ \\
\text { Negative } \\
+ \\
\text { Negative } \\
+\quad+ \\
\text { Negative } \\
\text { Negative }\end{array}+$ \\
\hline
\end{tabular}

The polymer powder consists of polymethylmethacrylate granules $97.5 \%$ and benzoyl peroxide $2.5 \%$, the latter being the activator. Patch tests to this powder were negative. A patch test to benzoyl peroxide was positive. It seems unlikely that the polymer powder itself was responsible for the dermatitis. It cannot be excluded that benzoyl peroxide became extracted by the monomer and was carried into the skin and there produced a reaction additional to that of the methylmethacrylate.

Patch tests were carried out to test the penetration of the rubber gloves. Fingers of a rubber glove were cut off. In one finger a small amount of polymer powder was carefully inserted into the tip. Into another a fresh mixture of monomer liquid and polymer powder was placed. Into a third finger a small piece of gauze moistened with monomer was inserted. All fingers were sealed with Sellotape and applied as patch tests. The monomer and the monomer and polymer mixture gave strong reactions. The polymer powder gave a negative reaction. The patch tests results are set out in detail in the Table.

It was thought desirable to test penetration of the rubber glove by an in-vitro method. This was done as follows. A small amount of polymer powder was placed inside the tip of a glove finger, a test-tube was then inserted into the glove finger which was then immersed into a bath of monomer liquid in such a way that no monomer could pass over the top. After five minutes the glove finger was removed from the solution and left to dry in air. Thirty minutes later the testtube was removed from the finger and the polymer powder was found to have set solid. This experiment was repeated a number of times and gave consistent results. The conclusion was drawn that acrylic monomer could readily penetrate an intact rubber surgical glove. Heavier household rubber and polyvinyl chloride gloves are not penetrated in the conditions described above.

\section{BACTERIOLOGICAL EXPERIMENTS}

Bacteriological experiments were made to ascertain whether acrylic monomer renders rubber gloves permeable to bacteria. Skin is notoriously difficult to sterilize (Lowbury et al., 1963), and the skin flora is re-established quite quickly even after the most vigorous "scrubbing up" procedures. Since it has been shown that monomer can pass through surgical gloves the question arose whether the normal flora of the surgeon's hands could also leak out through the gloves into the open wound when the cement was being inserted into the bone.

The monomer and polymer powder as supplied by the manufacturer are sterile and Charnley (1970) reported that monomer has bactericidal activities. We have studied the effect of monomer on three species of bacteria and have examined the possibility that these bacteria are able to pass through rubber gloves treated with monomer.

\section{Methods}

Bacteria.-Overnight nutrient broth cultures of Staphylococcus aureus, Escherichia coli, and Bacillus subtilis were used.

Bactericidal Effects of Monomer.-The method used was very similar to that of Charnley (1970) and detected the effect of monomer on the viability of bacteria which had been previously inoculated on to strips of sterile filter paper. Our strains of B. subtilis and Staph. aureus survived a 60-minute immersion period in monomer but $E$. coli survived for only 10 minutes.

Effect of Monomer on Permeability of Gloves to Bacteria.The apparatus illustrated was sterilized by autoclaving. Puritee glove fingers were used in all experiments. In one set of

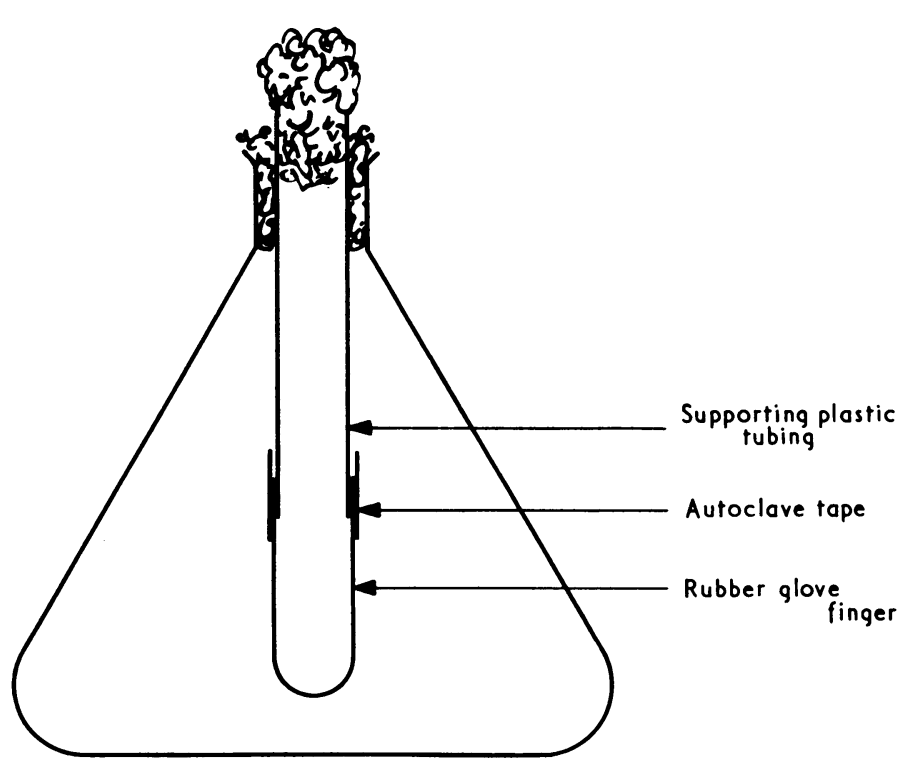

Apparatus used in bacteriological investigations of the effect of monome on rubber gloves.

experiments the glove fingers were immersed in monomer for periods of up to one hour. The apparatus was then reassembled and $10 \mathrm{ml}$ of broth culture of E. coli, B. subtilis, or Staph. aureus was pipetted into the finger. Sterile broth was poured into the flask so that $3 \mathrm{~cm}$ of the finger was immersed. Control experiments used untreated glove fingers. The sets of apparatus were incubated at $37^{\circ} \mathrm{C}$ for up to 10 days and the nutrient broth was examined daily for bacterial growth. In other experiments the broth cultures were pipetted inside untreated fingers and these were then immersed in monomer. These flasks were shaken frequently and samples of monomer were removed over a one-hour period and added to sterile nutrient 
broth. After vigorous shaking the broths were incubated at $37^{\circ} \mathrm{C}$ for five days and were examined daily for bacterial growth.

\section{Results}

No evidence was obtained from either series of experiments that bacteria passed through the glove fingers that had been treated with monomer. The control experiments also gave negative results. The organisms in the broth cultures within the glove fingers remained viable over the course of the experiments.

\section{Comment}

Allergy to acrylic resins is well known. Sensitivity may be to the monomer or to one of the additives (Calnan and Stevenson, 1963). In the present case it seems evident that there is sensitivity to the methylmethacrylate itself and that the sensitivity to the benzoyl peroxide is of marginal importance. In medicine self-curing resin is used in orthopaedics in hip surgery (Charnley, 1970), in replacement arthroplasty of the elbow joint (Dee and Sweetnam, 1970), in a procedure to stabilize the spine (Knight, 1959), and in the treatment of intracranial aneurysms (Dutton, 1959).

The penetration of the rubber gloves was an unexpected finding and in fact delayed the diagnosis in this case. The clinical implications are twofold: firstly, that dermatitis and possibly toxic effects may occur as the result of penetration; and, secondly, that chemical damage to rubber gloves might allow bacterial penetration. From the dermatological point of view acrylic monomer can readily penetrate surgical rubber gloves and no doubt carry other substances with it, the same may well apply to acetone and other solvents. It is possible that some cases of dermatitis of the hands may have been incorrestly interpreted as the result of unawareness of the permeability of rubber. Such cases may have been diagnosed as rubber glove dermatitis, for inquiry among colleagues reveals that a number of cases of rubber glove dermatitis give negative patch tests to rubber and rubber additives. It is among surgeons and theatre staff dealing with acrylics that such factors operate, but there may be other situations involving other solvents.

As regards the bacteriology, under the conditions of the experiments reported above it seems that bacteria do not pass through treated gloves. Since B. subtilis and Staph. aureus could withstand the effects of monomer for one hour, had they passed through the glove fingers in the second series of experiments they should have been detected in the monomer surrounding the glove fingers. During the course of an operation, however, the stresses to which gloves are subjected are somewhat different from the situation in these experiments, since the surgeon would be exerting great pressure on the gloves when packing bone cavities with cement. The possibility that under these conditions organisms could be forced through the gloves into the tissues cannot be totally ruled out. It is possible that the untoward effects of monomer could be prevented by wearing heavy gauge rubber or polyvinyl chloride gloves during the appropriate stages of an operation.

We have pleasure in acknowledging the help and advice of Dr. R. H. Muller, of J. G. Franklin \& Sons Ltd., Mr. G. S. Thurman, of C.M.W. Laboratories Ltd., Mr. S. W. Rogers and Mr. E. R. Howells of I.C.I. and Professor C. F. Barwell, of the bacteriology department of the London Hospital Medical College. We also wish to thank Mrs. S. J. Fitzgerald, who helped in some of the bacteriological experiments.

\section{References}

Calnan, C. D., and Stevenson, C. J. (1963). Transactions of the St. Fohn's Hospital Dermatological Society, 49, 9.

Charnley, J. (1970). Acrylic Cement in Orthopaedic Surgery. Edinburgh, Livingstone.

Dee, R., and Sweetnam, D. R. (1970). Proceedings of the Royal Society of Medicine, 63, 653.

Dutton, J. (1959). British Medical fournal, 2, 597.

Kutton, J. (1959). British Medical

Lowbury, E. J. L., Lilly, H. A., and Bull, J. P. (1963). British Medical Fournal, 1, 1251 .

\title{
Lymphocyte Sensitization in Sarcoidosis
}

\author{
E. A. CASPARY, E. J. FIELD
}

British Medical fournal, 1971, 2, 143-145

\section{Summary}

Nineteen patients with sarcoidosis have all been shown to have lymphocytes in their blood sensitized to several antigens, including purified protein derivative of tuberculin and Kveim agent, though they had negative or greatly reduced Mantoux reaction. Two patients who repeatedly failed to "convert" after B.C.G. inoculation showed the same cell sensitization phenomena. No explanation can be offered for this anomaly.

\footnotetext{
Medical Research Council, Demyelinating Diseases Unit, Newcastle General Hospital, Newcastle upon Tyne NE4 6BE

E. A. CASPARY, M.SC., Member of M.R.C. Scientific Staff

E. J. FIELD, M.D., F.R.C.P., Professor of Experimental Neuropathology
}

\section{Introduction}

Some years ago we found increased antibody titre to a number of antigens in the serum of patients suffering from sarcoidosis (unpublished). The antigens tested comprised encephalitogenic factor (E.F.), a basic protein of histone-like character extracted from human brain (Caspary and Field, 1965); purified protein derivative of tuberculin (P.P.D.); bovine serum albumin; egg albumen; and cow vaginal mucus, the latter being an "exotic" antigen. Recently an electrophoretic method of assessing lymphocyte sensitization to different antigens has been developed (Field, Caspary, Hall, and Clark, 1970; Caspary and Field, 1971a) primarily for the study of "autoimmune" disease of the nervous system (Caspary and Field, 1971b). Among control subjects examined was one patient with sarcoidosis. Because of the unexpected results a small series was collected, which forms the subject of this preliminary communication. 